\title{
Recent Surveys in Northern Patagonia
}

\section{Author(s): Bailey Willis}

Source: The Geographical Journal, Vol. 40, No. 6 (Dec., 1912), pp. 607-615

Published by: geographicalj

Stable URL: http://www.jstor.org/stable/1778218

Accessed: 22-06-2016 16:46 UTC

\section{Your use of the JSTOR archive indicates your acceptance of the Terms \& Conditions of Use, available at}

http://about.jstor.org/terms

JSTOR is a not-for-profit service that helps scholars, researchers, and students discover, use, and build upon a wide range of content in a trusted digital archive. We use information technology and tools to increase productivity and facilitate new forms of scholarship. For more information about JSTOR, please contact support@jstor.org.

The Royal Geographical Society (with the Institute of British Geographers), Wiley are collaborating with JSTOR to digitize, preserve and extend access to The Geographical Journal 
bridge which Korea made to this island realm. She borrowed generously, but she has modified generously. The Japanese character is conservative. That which she has taken from China, like that which she has taken from the modern world, she has adapted to her uses and to her national ideals. Take another example. Crete in 1800 B.c. was one of the most original islands we have ever found, but the indications are that it also borrowed to some extent from Egypt, to some extent apparently from other neighbouring lands.

The President: I am sure before you go you will wish me to express your sentiments of gratitude to Miss Semple. We have had an unusual experience to-night, for in place of the somewhat cautious compliments that are usually addressed to the reader of the paper, we have listened to a series of searching questions put by an intrepid professor, and responded to by Miss Semple with a spirit and ability that has given us all the greatest delight. Three things struck me chiefly about the paper: first, the extremely keen and observant eye which Miss Semple must have directed to the objects of her inquiry; secondly, the wonderful beauty of the slides she showed us, many of them from photographs taken by herself; and, thirdly, her unusual power, equally visible in the printed paper which she did not give, and in the extemporaneous lecture which she did give, of deducing from the phenomena of material existence large generalizations and scientific laws. With these words I will ask you to join me in carrying a hearty vote of thanks to Miss Semple for her lecture.

\section{RECENT SURVEYS IN NORTHERN PATAGONIA.}

\section{By BAILEY WILLIS.}

Survers of the boundaries, rivers, and railways of Argentina have during the past ce.tury extended a network of measurements around and over the country, covering it with a finer or larger mesh of surveyed lines and affording a general knowledge of the principal geographic features. The railway network is comparatively close over the Province of Buenos Aires and neighbouring central provinces, but lines have only recently begun to extend in Rio Negro, Chubut and Santa Cruz, the territories that represent what was formerly known as Patagonia. Although occupied by immense herds of sheep, and smaller numbers of cattle and horses, in part owned by estancieros but in general by nomadic squatters, these territories are still to a great extent known to geographors only through the itineraries of explorers. An Argentine statesman, Ezequiel Romos-Mexia, has for the past six years shaped the policies of the Ministries of Agriculture and of Public Works, which he has successively filled, toward the development of the national territories and has pursued the purpose of building railways into the so-called desert regions of Patagonia to promote settlement and change them into populous provinces, as has been done with the "Great American Desert" of the United States. Three lines of railway have been begun under the Minister's administration, one from Puerto Deseado in Santa Cruz, another from Rivadavia in Chabut, and the third from Puerto San Antonio in Rio Negro. The surveys to which this article 
relates have been made during the past year in the zone to be traversed by the last named, the railway which was originally projected to connect San Antonio on the Atlantic with Lake Nahuel Huapi in the Andes, and is now designed to become a transcontinental trunk line extending with the co-operation of Chile to Valdivia on the Pacific. Branches will be thrown out from it in the Argentine Andes, one southward 150 miles to the flourishing colony of the 16 of October, the other northward 100 miles to the old settlements of San Martin Jumin de los Andes. Both these branches and the extension to Chile traversed regions of great scenic beauty in the Cordillera, often called the Switzerland of Argentina. Tourist travel will eventually be attracted, and union of the Argentine and Chilian railway systems by broad gauge road with moderate grades cannot fail to be of great advantage to the intercourse between the two countries.

Francesco P. Moreno, the Argentine explorer of Patagonia, originally pointed out the route from San Antonio to Lago Nahuel Huapi, the ocean port and the great lake in the same latitude being obviously future centres of population whose growth he foresaw with youthful enthusiasm on his first journey in 1879 , when the region was still occupied by hostile Indians. His itineraries were the principal source of information up to 1904, when Ramon Guerrera made a topographic reconnaissance with triangulation of a considerable area south-east of Nahuel Huapi, which did not, however, extend to the eastern half of the continent. Guerrera's map was never published, nor his work continued, and so it was that engineers, starting from San Antonio, projected the railway westward across Patagonia toward Lago Nahuel Huapi, with but very inadequate knowledge of the country they must cross. Railroad building in Argentina has been mostly in the vast plains of the central provinces, and the treeless plateaus of Patagonia are not so different in aspect as to immediately suggest the need of careful preliminary topographic surveys before striking out on a direct line for the objective point. But when difficulties were met, it became evident that accurate topographic maps and geologic stadies were necessary to overcome them.

Argentina has much in common with the United States in the problems which her territory presents with reference to surveying and settlement. Vast areas are to be made known and populated according to the resources they offer, and the essential information must be gathered rapidly, with economy, yet with adequate accuracy. Patagonia may be compared topographically with the high plains of Kansas and Texas, and as to climate in part with Arizona, regions which have been greatly aided in their development by official government surveys by specially trained men. The Minister of Pablic Works, Ramos-Mexia, applied to the United States Government through its minister, Mr. Sherril, and the writer, a geologist of the United States Geological Survey, was given leave of absence to enter into a special service with the Argentine government, by which he 


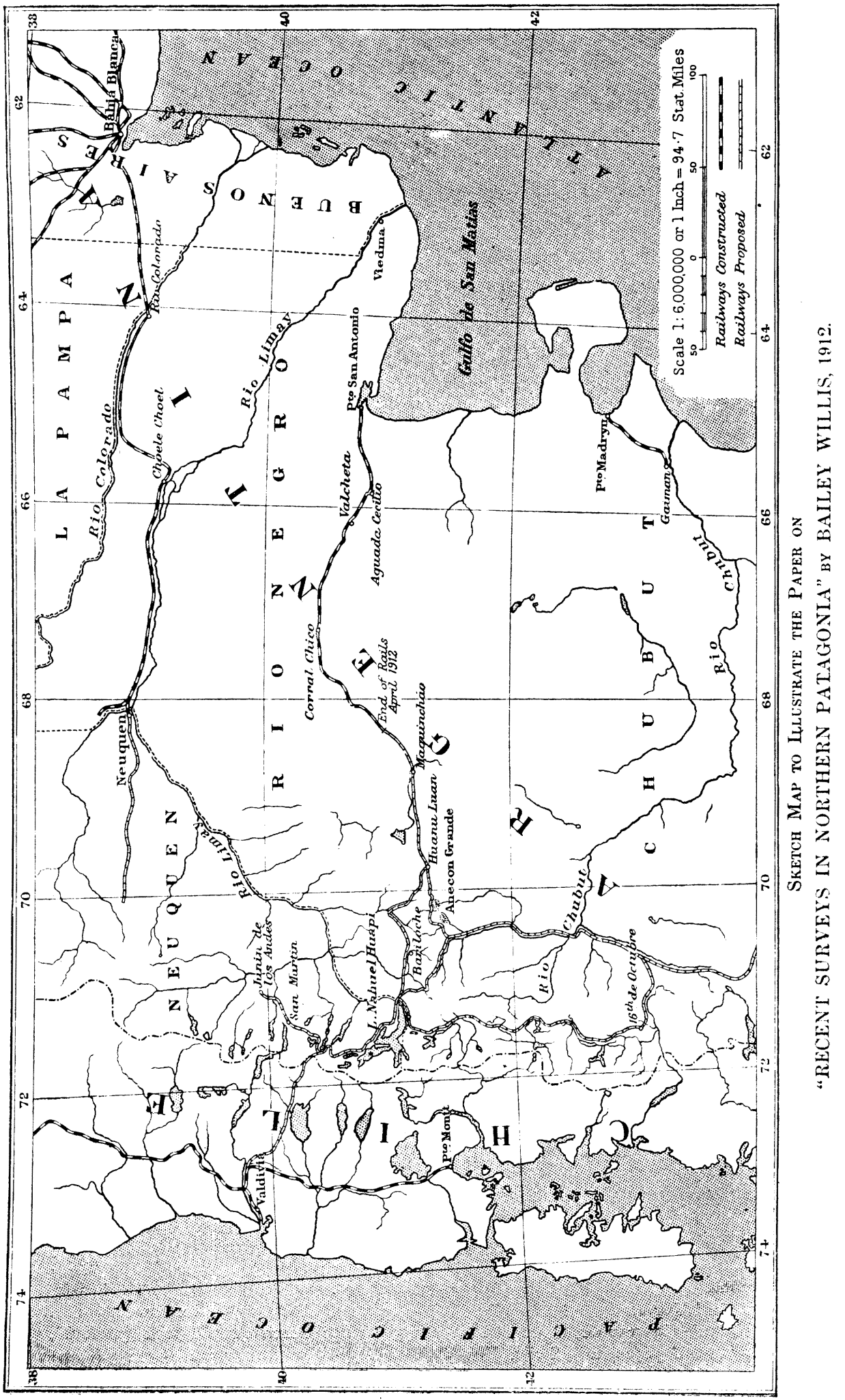


was authorized to engage five North American associates and three Argentine engineers.*

Surveys in Patagonia (territory of hio Negro) were begun in March, 1911, and will be continued till March, 1913, under the existing agreement. The first winter season from March to October was spent in the eastern portion of the Territory, with Valcheta as headquarters. The dry, moderately cold weather was very favourable, high winds alone interfering occasionally with continuous field work. The railroad had already been built and was in operation beyond the district under survey, to Kilometro 326 (203 miles), and the work was greatly facilitated by the ready transportation along the line. A passenger coach and several baggage cars were placed at the disposal of the Comision, and were fitted up as offices, photographic laboratory, and central commissary. Triangulation, a well-controlled line of levels, and topographic surveys with plane-table were extended from San Antonio westward. The railroad was taken as a median line, and the topographic surveys adjacent to it were carried out on a scale of $1: 100,000$, with contours 10 metres apart in altitude, covering a zone of 10 kilometres (6 miles) in total width. During the first six months, this work extended over about 220 kilometres (137 miles) of the line, i.e. over 2300 square kilometres (888 square miles). Concurrently surveys on a scale of $1: 200,000$, with contours 20 metres (65 feet) apart in altitude, were carried out, outside of the more detailed work between Valcheta (Kil. 109 (68 miles)) and Corral Chico (Kil. 216 (134 miles)) covering about 4000 square kilometres (1545 square miles). Geological studies and an examination of the soils, waters, and conditions affecting grazing, were made as the topographic work progressed, the maps being photographed for the specialist's use.

The essential need of the railroad in this eastern district is good water. The rainfall varies periodically from 200 to 300 millimetres ( 8 to 12 inches) per annum, and diminishes as we recede from the coast to about halfway across the continent, thence toward the Cordillera it increases more rapidly. San Antonio and the railway depended entirely upon rainwater collected in cisterns or obtained in small amount from tube-wells sunk in the sand-hills along the coast, until the rails reached Valcheta, 109 kilometres (68 miles) distant; there a clear and constant stream runs across the arid plateaus, and from it water is hauled daily in tank cars to the city. A small spring, "Aguada Cecilio," had been tapped and various wells had been sunk between San Antonio and Valcheta, but

* The survey is officially known as the "Comisión de Estudios Hidrológicos del Ministerio de Obras Publicas," and is composed of : Bailey Willis, Geologist and Chief, U.S. ; E. E. Frey, Secundo, Argentine ; C. L. Nelson, W. B. Lewis, Topographers, U.S. Geological Survey; J. R. Pemberton, C. Washburne, Geologists, Stanford University, California, and U.S. Geological Survey; Wellington D. Jones, Economic Geographer, Chicago University; Walter Graenacher, Otto Lugenbuehl, Assistant Topographers, Swiss. 
the water was more or less saline. Two deep wells, 10 s metres (345 feet) deep at San Antonio, and 270 metres (886 feet) deep 62 kilometres (39 miles) west of the city, were unsuccessful. Nevertheless it had been the hope of the minister that geologic studies would develop artesian waters. They showed, on the contrary, that artesian waters do not exist in eastern Rio Negro, and had they been made a year sooner, they would have prevented the needless expenditure for the two deep wells.

Northern Patagonia is an old, deeply eroded, continental mass, com-

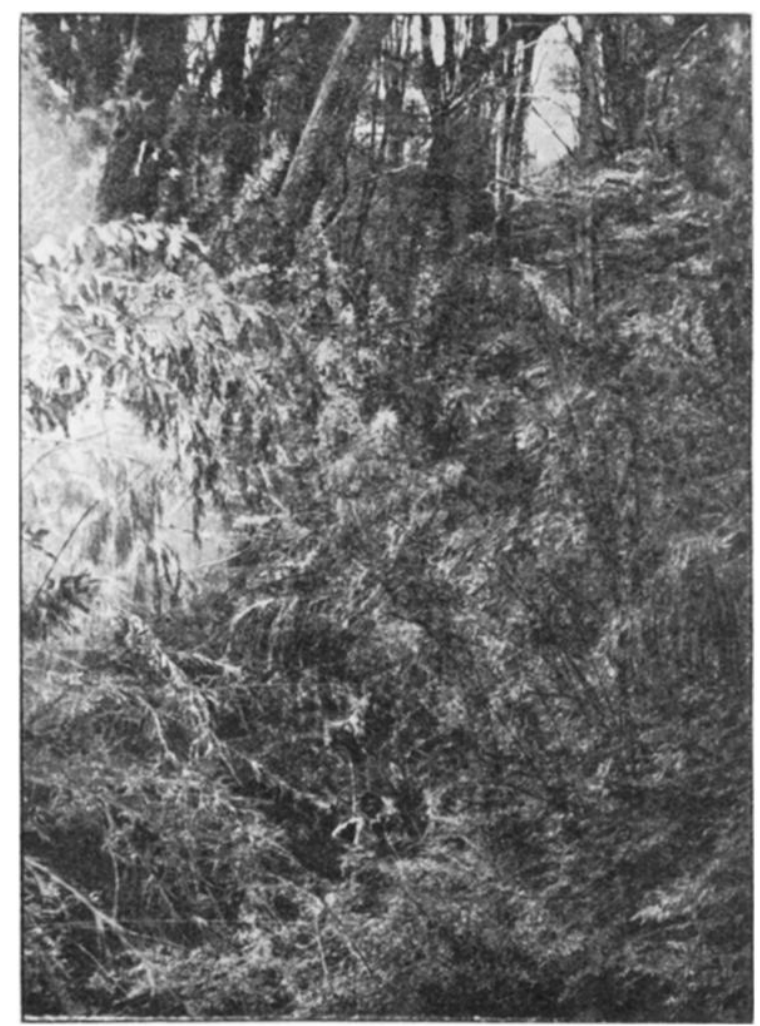

FOREST OF THE ARGENTINE ANDES, NORTH OF LAKE NAHUEL HUAPI. THE JUNGLE GROWTH IS A VARIETY OF BAMBOO, AND THE TREES ANDEAN BIRCH.

posed of metamorphic slates, probably Paleozoic, and cut by eruptive granites and rhyolites. Over this basement occur thin marine and freshwater sediments, probably Eocene, which are capped by flows of basalt and andesite, and are irregularly distributed in more or less extensive remnants. Near the coast are younger Tertiary or Pleistocene clay and gravel deposits, with layers of secondary limestone.

As these conditions excluded the possibility of finding a water supply for the city and railway by artesian boring, attention was turned to the 
Arroyo Valcheta, the clear, constant stream already referred to, and it was found that the waters could be impounded in a reservoir from which they would flow to San Antonio by gravity. The possibility of thus supplying the city had not been recognized in advance of the topographic surveys which demonstrated it, and had not been looked for, chiefly because the railway between San Antonio and Valcheta crosses a high plain nearly 50 metres ( 164 feet) above the Arroyo Valcheta at the railroad. Conducting the water from upstream into a high reservoir and finding a lower pass in the ridge solved the problem.

The Arroyo Valcheta is of a type common in the warped plateaus of Patagonia. Its waters gather from rain and snow in elevated lava fields, 1000 metres ( 3281 feet) or more above the sea, and finding no well-defined surface channels trickle underground till they issue in large springs at the base of the bold escarpment. Thence the stream flows in meadows and swamps, constantly losing by evaporation in its course and finally dies in a salt lake in a basin without outlet to the sea. The diversion of a part of its waters to a reservoir will redeem a large area suitable for growing alfalfa and turn a waste into use, as well as provide the necessary supply for the railway and San Antonio, for which no other source seems available. The natural reservoir from which the head springs issue, the lava plateau surmounted by volcanic peaks that rise to 1800 metres ( 5906 feet) above the sea, appears to guarantee an adequate and constant flow, and records of twenty-three years show that during that period it never has failed.

The explorations, detailed surveys, and engineering plans for the Valcheta reservoir and pipe line occupied the force till October, when the opening of spring made work possible in the high plateau region further west, where severer winter weather and heavy snow had previously prevented it.

In crossing the continent the railway rises from the Atlantic, not by a series of terraced steps, as has often been described, but by passing across interior basins from one plateau to another, the continental surface being warped, so that basins without outlets to the sea range from south-east to north-west between high plains. The plains grow higher towards the west. About midway of the continent, at Maquinchao, the valley, which corresponds to a depressed area, is 900 metres (2953 feet) above the sea, and with very gradual ascent it extends 100 kilometres ( 62 miles) west by north. The projected railway line follows it toward a conspicuous mass of volcanic peaks, of which the highest, Anecon Grande, somewhat exceeds 2000 metres ( 6562 feet) in altitude above the sea. The peaks are bold, rocky remnants of ancient volcanoes, loug since stripped of cinder and ash deposits, which are spread about them and to a great extent covered by later basalt flows. This mesa-surface lies between 1200 and 1600 metres (3937 to 5250 feet) above sea. It is cut by valleys and canyons 100 to 180 metres (328 to 590 feet) deep, which radiate from Anecon Grande, and shed their waters to the Rio Limay on the north or the Rio Chubut on the south. 
To reach Lago Nahuel Huapi, the railroad must traverse the rugged region of mesas and canyons about Anecon Grande in central northwestern Patagonia, and descend some 400 metres (1312 feet) into the pre-Andean depression into which the lake opens with an elevation of only 770 metres (2526 feet) above sea. Preliminary surveys for a line had sufficed only to make apparent the difficulties of the terraine, which are in fact greater from the point of view of the railroad engineer than the obstacles opposed to location by the Andes in this latitude. A general topographic survey of the region was ordered by the minister, and having been begun in November, 1911, was carried on till April, 1912. It resulted in the mapping of 4,000 square kilometres (1544 square miles)

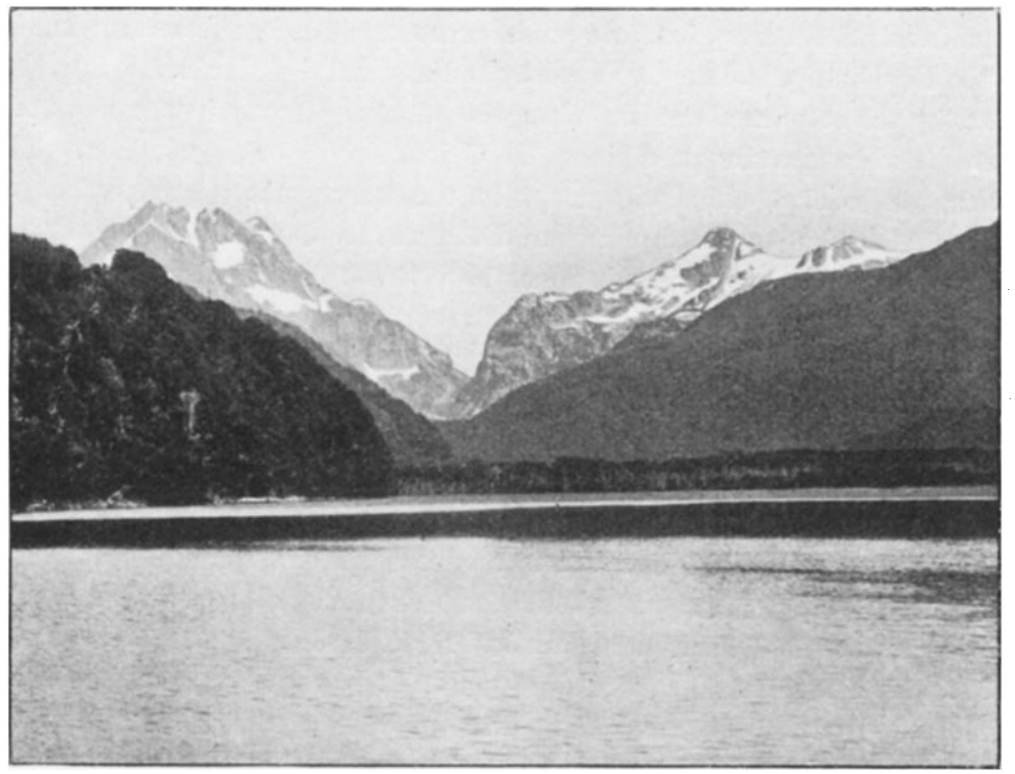

THE PASS OF THE CAJOU NEGRO, WITH LAGO VILLARINO IN THE FOREGROUND. THE TRANSCONTINENTAL RAILWAY FROM SAN ANTONIO TO VALDIVIA WILL PIERCE THE RANGE IN A TUNNEL A MILE LONG AT 3800 FEET ABOVE SEA IN THIS PASS.

on the scale of $1: 100,000$ with contours 20 (66 feet) to 20 metres, and the tracing of a practicable route for the broad gauge railway, which will have a total length of about 700 kilometres (435 miles) from San Antonio to Lago Nahuel Huapi. A well-controlled line of levels was carried through to the lake, and the network of triangulation was completed, uniting the Atlantic coast with the peaks of the Andes.

Lago Nahuel Huapi is a beautiful sheet of water, which, from its outlet to its head, extends 60 miles from the Pampas to the heart of the Andes. It lies like a deep canyon between sierras that rise 4000 feet above it, and branches irregularly among them as does Lake Lucerne, with which it is often compared. During nine or ten months of the year the mountains are 
snow-covered, and the scenery is strikingly Alpine. The boundary between Argentina and Chile follows the crest of the range round its headwaters and tributary lakes. The region had, therefore, been surveyed under the direction of Moreno, and excellent reconnaissance maps with sketch contours are included in the Argentine Evidence before the Arbitration Commission. Nevertheless there existed much uncertainty as to the practicability of a railroad from Lago Nahuel Huapi across the Andes to Chile, the very name of the Cordillera inspiring doubt in the minds of those unfamiliar with achievements of railroad building across mountain chains. To set these doubts at rest, and to complete the plan of the transcontinental line, the minister ordered an exploration of the mountains and passes north and west of Nahuel Huapi. On conferring with those best acquainted with the region, two passes were suggested; one a route known as the Puyehue pass, long ago used by Indians and Spaniards and in recent years by the settlers about the lake; the other a gateway in the mountain crest between granite precipices, El Cajon Negro or Black Box. The latter was almost unknown except to the surveyor's telescope, but an eminent Chilian engineer, Enrique Döli, at present Director of Public Works for Chile, had visited it about 1900 to set the boundary monument, and was of the opinion that it could be reached by railway.

The approach to Puyehue pass is by profound gorges, overhung by cliffs that suggest Yosemite scenery; the ascent could be accomplished only by steep grades; and the summit being broad, almost plateau like, the line would be exposed for a long stretch to obstruction by winter snows at an elevation of 1200 to 1300 metres ( 3937 to 4265 feet). The Cajon Negro, on the other hand, can be reached by moderate grades, through beautifully forested valleys, past exquisite lakes, and the crest of the Sierra can be pierced by a tunnel about a mile in length at an elevation of 1180 metres (3873 feet) above sea. The exploration of these routes was accomplished during the early summer and plane-table surveys were made covering the line by the Cajon Negro, so that we may now say that the topography of the railway route from San Antonio to the crest of the Andes has been mapped and the preliminary location determined. The surveys are being continued with the further object of fixing the railway location in detail and of completing the scientific and economic studies of the transArgentine zone on the 41 st parallel of south latitude. It would not be inappropriate to call this the Forty-first Parallel Survey of South America.

The territory of Rio Negro, which is thus to be traversed and developed by a national railway, comprises two distinct regions, whose natural features and conditions, considered with reference to their future economic uses, are so unlike that they should become separate provinces. The treeless pampas, which extend from the Atlantic to the foothills of the Cordillera, are adapted to sheep and cattle-raising with auxiliary agriculture of pasture crops. With the exception of the Rio Negro valley, which is not here considered, there is but a very small area that can be irrigated, and 
cultivation will depend upon the waters which accumulate in the high lavaplateaus and sweep through the gravels of the wide seemingly arid valleyplains. Where the fine eolian soil, which in many such valleys is from 1 to 2 metres (3 to 6 feet) deep, is within reach of ground water, alfalfa may be grown advantageously. Otherwise the Pampas of Rio Negro, which cover about 65,000 square miles, must always be given up to grazing, and the Government policy with reference to the public lands and territorial administration should be directed to encourage that industry. To that end the Minister of Agriculture will initiate a policy of leasing public lands for grazing on leases of thirty years under liberal conditions.

The Cordilleran district of Rio Negro, together with the like portions of Chubut and Neuquen, constitutes a unique region among Argentine territories, distinguished by its mild climate, abundant rainfall, large rivers and beautiful lakes, great water powers, and three important raw materials-wood, hides, and wool. Each of these conditions exists in some measure in other parts of the Republic, but their association, especially with water-power, distinguishes this region from any other within the Argentina tariff wall unless we except the semi-tropical territories of Entre Rios and Missiones. This Cordilleran district, with an area of about 20,000 square miles, is adapted to intensive farming, manufacturing, and a dense population which will naturally be recruited from England, Germany, Switzerland, France, and the United States. It is one of the richest possessions of Argentina, a section of the best Andean territory, won from Chile in the arbitration by King Edward, through the patriotic and indefatigable labours of Moreno. Justice should some day require that it be set apart as the Territorio de Moreno, in honour of the great explorer of its valleys and the staunch defender of Argentine sovereignty over its rivers, lakes, and lands.

Argentines have not realized the wealth which these provinces offer for development. Their far-seeing statesman, Ramos-Mexia, has been strenuously opposed in his efforts to make Patagonia accessible, prosperous, and valuable to the nation; but he is succeeding, and now that the resources of the region are becoming known, it may be hoped that his persistent purpose will be liberally supported and carried to completion.

\section{SOME NOTES ON MY 1912 EXPEDITION TO THE SIACHEN OR ROSE GLACIER.}

By Mrs. FANNY BULLOCK WORKMAN.

As reported in 1911 in the Geographical Journal, Dr. W. Hunter Workman and I, after completing our exploration among the Hushe glaciers and those of the Kondus system, crossed to the Saltora valley* and traversed the Bilaphon La, $\uparrow 18,500$ feet, to the Siachen or Rose glacier on August 19.

* The usual spelling is Saltoro.

+ Local name for the Saltoro pass. Geographical Journal, vol. 35, p. 622. 